\title{
Four new monoraphid diatom species (Bacillariophyta, Achnanthaceae) from the Maritime Antarctic Region
}

\author{
Kateřina KOPALOVÁ ${ }^{1,2}$, Ralitsa ZIDAROVA ${ }^{3} \&$ Bart VAN DE VIJVER ${ }^{4,5}$ \\ ${ }^{1}$ Charles University in Prague, Faculty of Science, Department of Ecology, \\ Viničná 7, CZ-12844 Prague 2, Czech Republic. \\ ${ }^{2}$ Academy of Sciences of the Czech Republic, Institute of Botany, Section of Plant Ecology, \\ Dukelská 135, CZ-37982 Třeboň, Czech Republic. \\ ${ }^{3}$ St. "Kliment Ohridski” University of Sofia, Faculty of Biology, Department of Botany, \\ 8 Dragan Tzankov Blvd., Sofia 1164, Bulgaria. \\ ${ }^{4}$ Botanic Garden Meise, Department of Bryophyta \& Thallophyta, \\ Nieuwelaan 38, B-1860 Meise, Belgium. \\ ${ }^{5}$ University of Antwerp, Department of Biology, ECOBE, \\ Universiteitsplein 1, B-2610 Wilrijk, Antwerpen, Belgium. \\ 1,2 k.kopalova@hotmail.com (corresponding author) \\ ${ }^{3}$ zidarova.r@gmail.com \\ ${ }^{4,5}$ bart.vandevijver@plantentuinmeise.be
}

\begin{abstract}
Four monoraphid taxa belonging to the genera Achnanthes, Psammothidium and Planothidium were found during the ongoing taxonomic revision of the freshwater and limno-terrestrial diatoms of the Maritime Antarctic region. The present paper describes these four taxa as new based on detailed light and scanning electron microscopy observations: Achnanthes kohleriana Kopalová, Zidarova \& Van de Vijver sp. nov., Planothidium wetzelectorianum Kopalová, Zidarova \& Van de Vijver sp. nov., Psammothidium confusoneglectum Kopalová, Zidarova \& Van de Vijver sp. nov. and Psammothidium superpapilio Kopalová, Zidarova \& Van de Vijver sp. nov. The morphology and ecology of all four taxa are discussed and the species are compared with morphologically similar taxa.
\end{abstract}

Keywords. Achnanthes, Planothidium, Psammothidium, new species, biogeography, Antarctica.

Kopalová K., Zidarova R. \& Van de Vijver B. 2016. Four new monoraphid diatom species (Bacillariophyta, Achnanthaceae) from the Maritime Antarctic Region. European Journal of Taxonomy 217: 1-19. http://dx.doi. org/10.5852/ejt.2016.217

\section{Introduction}

The past 10 years, the non-marine diatom flora of the Maritime Antarctic Region has been undergoing a serious revision following a fine-grained taxonomy that has been widely accepted nowadays. Prior to this revision, only very sparse literature existed on the diatom composition of the Antarctic region and the reported diatom flora was based on a very broad species concept, making the use of this literature in biogeographical and biodiversity studies less appropriate due to the many inconsistencies in the diatom 
identification. The revision resulted in the description of a large number of new taxa, predominantly in biraphid genera such as Luticola D.G.Mann (Kopalová et al. 2011, Zidarova et al. 2014, Kohler et al. 2015), Navicula Bory (Van de Vijver et al. 2011), Pinnularia Ehrenb. (Zidarova et al. 2012) and Muelleria Freng. (Van de Vijver et al. 2010, 2014).

Apart from the biraphid genera, monoraphid diatoms represent likewise a considerable part of the diatom flora in the entire Antarctic region (including sub-Antarctica, Maritime Antarctica and the Antarctic Continent), both in number of species and number of individuals. Five genera have actually been regularly observed in Antarctic samples: Achnanthes Bory s.s., Achnanthidium Kütz., Karayevia Round \& Bukht., Planothidium Round \& Bukht. and Psammothidium Bukht. \& Round representing a total of 38 different species (Oppenheim 1994; Van de Vijver et al. 2002; Sabbe et al. 2003; Le Cohu 2005; Ohtsuka et al. 2006). In 2014, Van de Vijver \& Kopalová revised the genus Achnanthidium in the entire Antarctic region describing two new species. Analysis of the types of Planothidium lanceolatum (Bréb.) Lange-Bert. (Van de Vijver et al. 2013) and Achnanthidium exiguum (Grunow) Czarn. (Taylor et al. 2014), both often reported from the Antarctic region (Kellogg \& Kellogg 2002), and comparisons of the Antarctic populations earlier assigned to these two taxa, led to the justification of another three new diatom species. The present paper continues the studies on monoraphid diatom species in Antarctica and describes four new monoraphid taxa belonging to the genera Achnanthes s.s., Planothidium and Psammothidium based on detailed light and scanning electron microscopy observations: Achnanthes kohleriana Kopalová, Zidarova \& Van de Vijver sp. nov., Planothidium wetzelectorianum Kopalová, Zidarova \& Van de Vijver sp. nov., Psammothidium confusoneglectum Kopalová, Zidarova \& Van de Vijver sp. nov. and Psammothidium superpapilio Kopalová, Zidarova \& Van de Vijver sp. nov.

\section{Material and methods}

During several austral summers (2004, 2006, 2008, 2009, 2013), material for diatom analysis has been sampled from James Ross Island and the South Shetland Islands (Livingston Island, Deception Island). In order to obtain a broad overview of the diversity and distribution of the diatom communities on the island, samples have been taken from different habitat types: freshwater lakes, seepage areas, wet rocks, rivers and mosses (ranging from aquatic to dry terrestrial). Samples were fixed in the field with 3\% formaldehyde. Diatom samples for LM observation were prepared following the method described in Van der Werff (1955). Subsamples of the original material were oxidized using $37 \% \mathrm{H}_{2} \mathrm{O}_{2}$ and heating to $80^{\circ} \mathrm{C}$ for approximately $1 \mathrm{~h}$. The reaction was further completed by the addition of $\mathrm{KMnO}_{4}$. Following digestion and centrifugation (three times 10 minutes at $3700 \mathrm{x}$ g), the material free of organic matter was diluted with distilled water for sample mounting to avoid excessive concentrations of diatom valves on the slides. A subsample from the organic-free material was mounted in Naphrax ${ }^{\circledR}$ for diatoms community studies. The slides were analysed at BR using an Olympus BX53 microscope, equipped with Differential Interference Contrast (Nomarski). LM micrographs were taken using Olympus UC30 camera connected to the Cell Sense Standard program. For scanning electron microscopy (SEM), parts of the oxidized suspensions were filtered through polycarbonate membrane filters with a pore diameter of $1 \mu \mathrm{m}$, pieces of which were fixed on aluminium stubs after air-drying. The stubs were sputter-coated with a GoldPalladium layer of $20 \mathrm{~nm}$ and studied in a ZEISS ULTRA SEM microscope at $3 \mathrm{kV}$. Terminology follows Hendey (1964), Barber \& Haworth (1981), Round et al. (1990) and Lange-Bertalot (1993).

For the typification of the new species, we chose to use the entire slide as the holotype. In monoraphid diatoms, both valves of the same frustule show a different morphology, so two valves should be chosen to represent the holotype. Moreover, diatoms show a broad variability along their cell cycle making the choice for the entire population on the slide more obvious. 


\section{Results}

Class Bacillariophyceae Haeckel emend. Medlin \& Kaczmarska (Medlin \& Kaczmarska 2004)

Subclass Bacillariophycidae D.G.Mann in Round et al. (1990)

Order Achnanthales P.C.Silva (Silva 1962)

Family Achnanthidiaceae D.G.Mann in Round et al. (1990)

Genus Achnanthes Bory (Bory 1822)

Achnanthes kohleriana Kopalová, Zidarova \& Van de Vijver sp. nov.

Figs 1-24

\section{Etymology}

The species is named after our friend and colleague Dr. Tyler Kohler (Charles University in Prague and University of Boulder, Colorado, USA) in recognition of his diatom ecology work in the Dry Valleys of the Antarctic Continent.

\section{Type}

Deception Island, South Shetland Islands, Antarctica, sample D13 $\left(62^{\circ} 58^{\prime} 24.5^{\prime \prime} \mathrm{S} 60^{\circ} 43^{\prime} 03.2^{\prime \prime} \mathrm{W}\right)$ (leg. R. Zidarova), coll. date: 21 Jan. 2013 (holo-: slide no. BR-4436; iso-: slide PLP-292, University of Antwerp, Belgium).

\section{Description}

\section{Light microscopy (Figs 1-13)}

Frustules in girdle view bent, with concave raphe valve and convex rapheless valve (Fig. 13). Valves linear to linear-elliptic, with almost straight to weakly concave in the middle valve margins. Valve apices broadly rounded, not protracted. Valve dimensions $(n=24)$ : length $38-45 \mu \mathrm{m}$, width $9.0-10.5$ $\mu \mathrm{m}$. Raphe valve (Figs 1-6): raphe distinctly lateral, curved. Proximal raphe endings deflected to one side terminating in drop-like expanded pores. Distal raphe fissures elongated and hooked. Axial area $1 / 4-1 / 5$ of the valve width, almost linear, following the curvature of the raphe, not or only slightly widening toward the central area. Central area forming a rectangular to bow-tie-shaped fascia, lacking any striae near the margins. Transapical striae weakly to moderately radiate in the middle, becoming more radiate toward the apices, 11-12 in $10 \mu \mathrm{m}$. Areolae well discernible in LM, rounded, c. 14-18 in $10 \mu \mathrm{m}$. Rapheless valve (Figs 7-12): rapheless sternum narrow, located close to the valve margin. Striae parallel at the valve middle, becoming radiate toward the apices, 10-11 in 10 $\mu \mathrm{m}$. Areolae well discernible in LM, rounded, c. 14-18 in $10 \mu \mathrm{m}$.

\section{Scanning electron microscopy (Figs 14-24)}

Raphe valve (Figs 14-19): valve face weakly concave in the middle. Apices presenting a rather larger hyaline zone (Figs 14, 16). Raphe slightly curved with tear-drop-shaped, weakly deflected proximal raphe endings, not extending in the central area (Figs 14, 17). Distal raphe fissures running a deep groove, hooked, elongated, continuing onto the mantle, terminating beyond the last striae (Figs 14, 16). Striae uniseriate, composed of almost rounded areolae with slightly recessed foramina, occluded by cribra with rounded perforations (Fig. 15). Small pseudosepta present near the valve apices (Fig. 19). Internally, proximal raphe endings strongly hooked backwards toward the poles (Fig. 18). Distal raphe endings straight, finishing onto small helictoglossae (Fig. 19). Striae separated by strongly thickened virgae (Fig. 19). Areolae with rounded foramina and recessed cribra (Fig. 19). Rapheless valve (Figs 20-24): valve face weakly convex (Fig. 20). A strongly thickened hyaline marginal ridge present at the valve face/ mantle junction (Figs 20,21). Spines absent. Rapheless sternum narrow, located near the valve margin (Fig. 21), internally well discernible as a narrow hyaline line close to the valve margin (Fig. 24, arrows). Terminal orbiculi present on the valve mantle near the apices, occluded by a single, structureless silica 

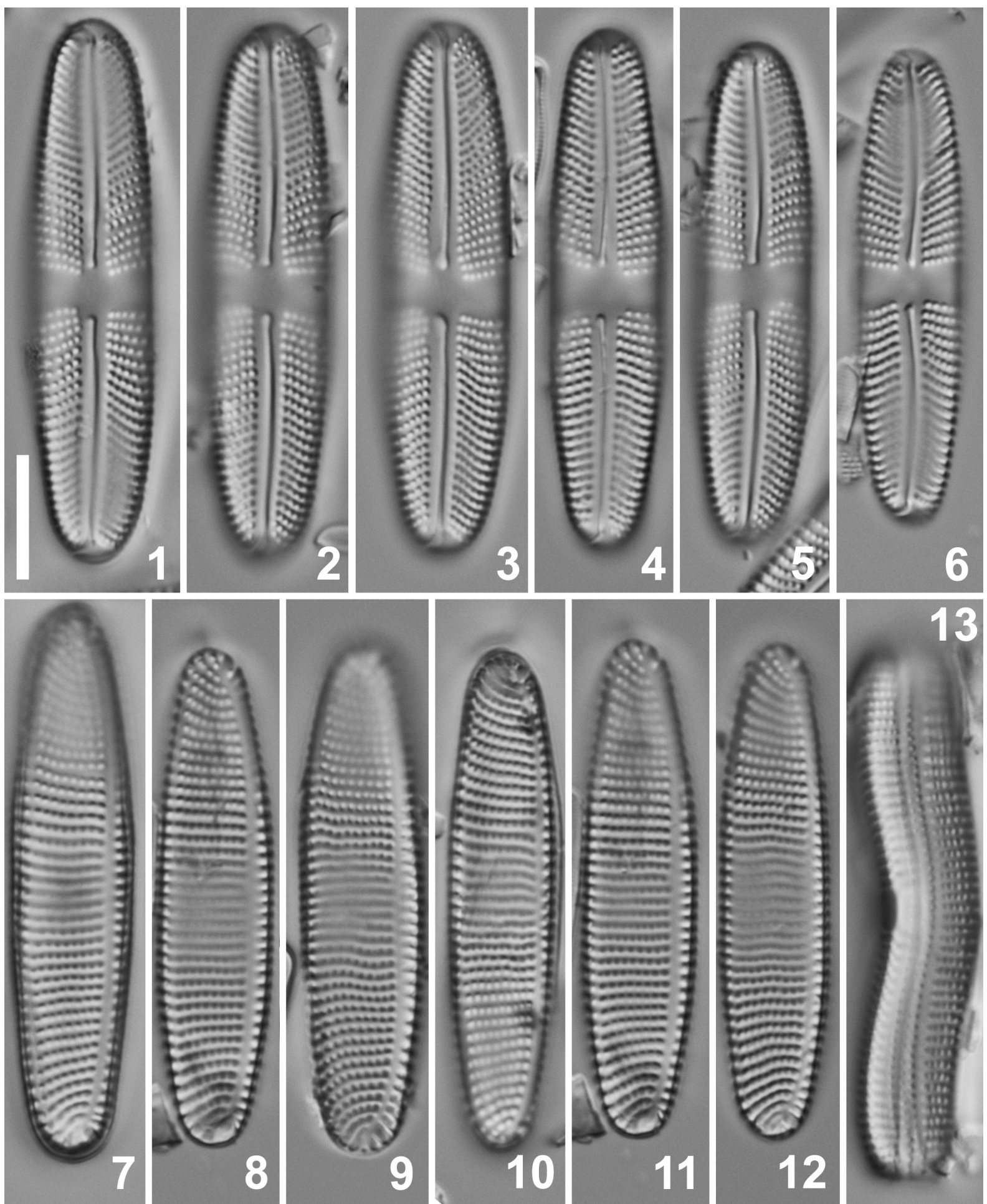

Figs 1-13. Achnanthes kohleriana Kopalová, Zidarova \& Van de Vijver sp. nov. Light micrographs of the type population from Deception Island (South Shetland Islands, Antarctica). 1-16. LM views of raphe valves. 7-12. LM views of rapheless valves. 13. LM view of a girdle view. Scale bar represents $10 \mu \mathrm{m}$. 

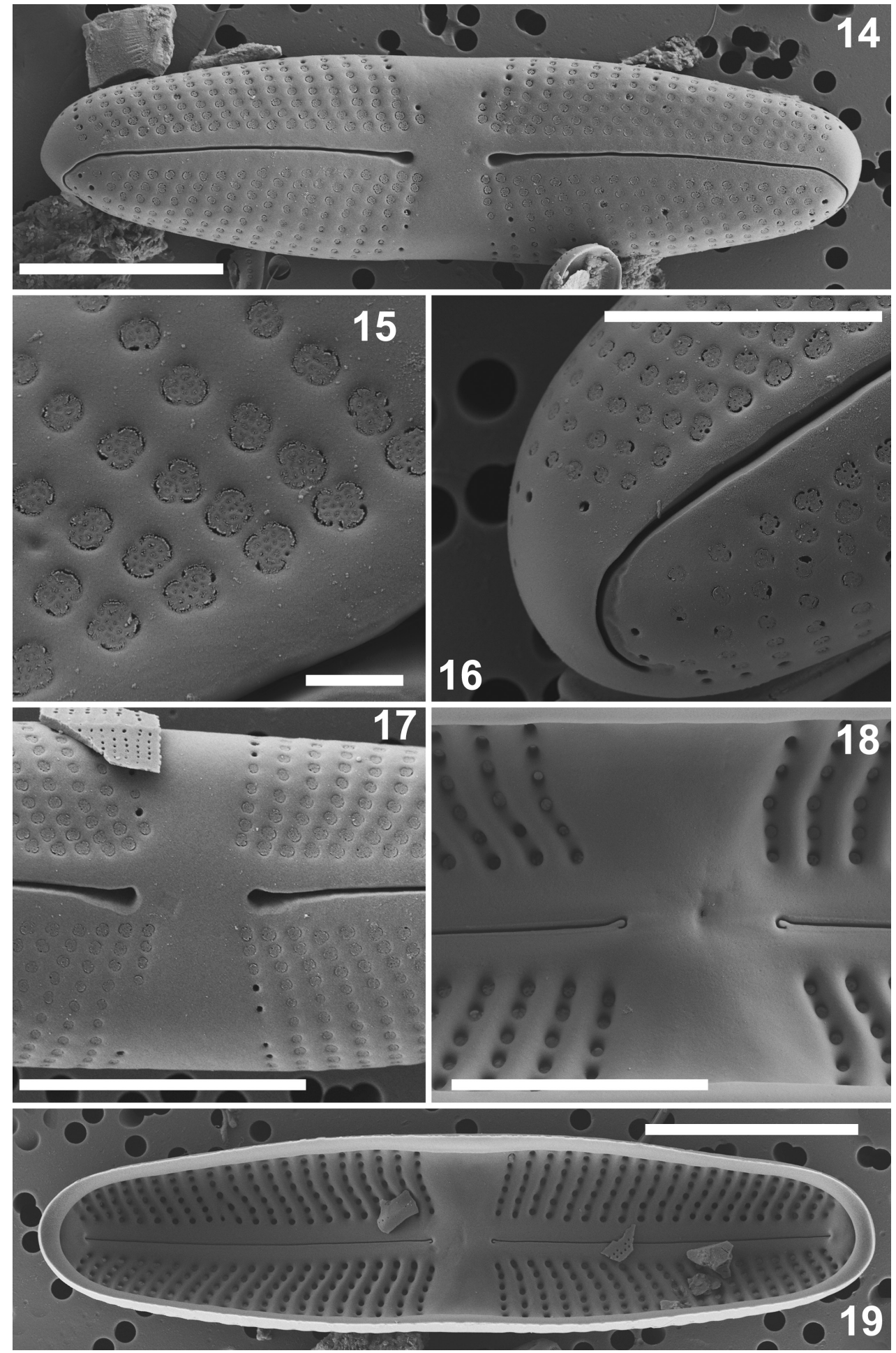

Figs 14-19. Achnanthes kohleriana Kopalová, Zidarova \& Van de Vijver sp. nov. Scanning electron micrographs of the type population from Deception Island (South Shetland Islands, Antarctica). 14. SEM external view of an entire raphe valve. 15. SEM external detail of the areolae with the typical cribrate structure. 16. SEM external view of the distal raphe ending. 17. SEM external detail of the central area. 18. SEM internal detail of the central area showing the hooked proximal raphe endings. 19. SEM internal view of an entire raphe valve. Scale bars represent $10 \mu \mathrm{m}$ for Figs $14 \& 19,1 \mu \mathrm{m}$ for Fig. 15 and $5 \mu \mathrm{m}$ for Figs $16-18$. 

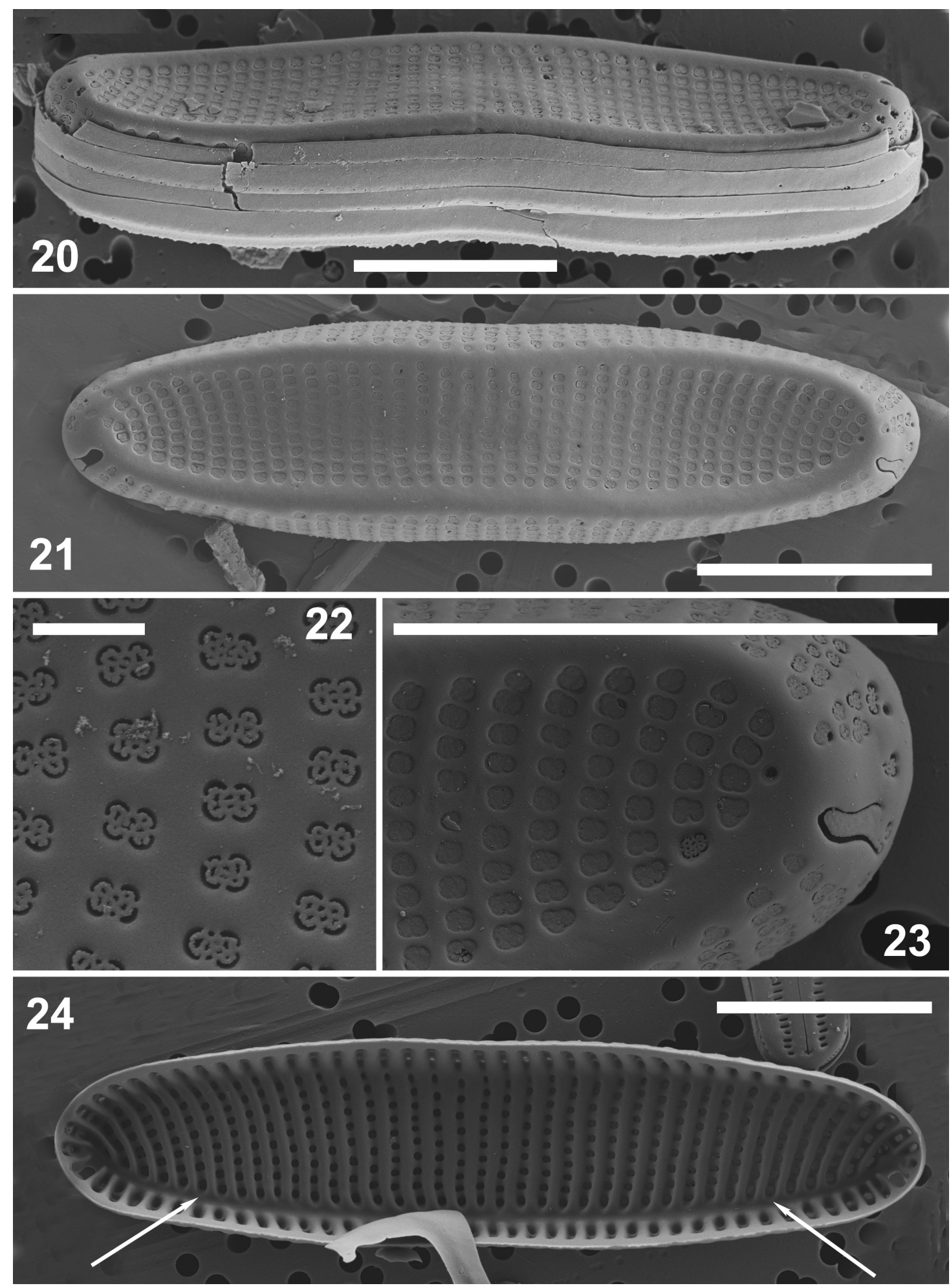

Figs 20-24. Achnanthes kohleriana Kopalová, Zidarova \& Van de Vijver sp. nov. Scanning electron micrographs of the type population from Deception Island (South Shetland Islands, Antarctica). 20. SEM girdle view of an entire frustule. 21. SEM external view of a raphe valve. 22. SEM external detail of the areolae with the typical cribrate structure. 23. SEM external detail of the apex with the typical terminal orbiculus. 24. SEM internal view of an entire rapheless valve. Arrows show the rapheless sternum. Scale bars represent $10 \mu \mathrm{m}$ for Figs 20, $21 \&$ 24, $1 \mu \mathrm{m}$ for Fig. 22 and $5 \mu \mathrm{m}$ for Fig. 23. 
flap (Fig. 23). Striae uniseriate on the valve face, becoming bi-seriate on the valve mantle (Fig. 23). Each stria composed of recessed rounded areolae, occluded by cribra with rounded or irregular perforations (Fig. 22). Internally, striae separated by strongly thickened virgae (Fig. 24). Areolae with rounded openings with noticeably recessed cribra (Fig. 24). Girdle composed of several open copulae, bearing a single row of rounded areolae, occluded by cribra (Fig. 20).

\section{Ecology and distribution}

So far Achnanthes kohleriana sp. nov. has been observed with certainty on several islands of the South Shetland archipelago (Livingston Island, Deception Island and King George Island). The largest population was found on Deception Island among wet mosses growing on a rock, located inland and far from the influence of sea sprays and with no nutrient input from sea birds or seals suggesting that the species is typically aerophilic. Other taxa present in the sample include Humidophila keiliorum Kopalová in Kopalová et al. (2015), H. deceptionensis Kopalová in Kopalová et al. (2015), Stauroneis pseudomuriella Van de Vijver \& Lange-Bert. in Van de Vijver et al. (2004), S. pseudoschimanskii Van de Vijver \& Lange-Bert. in Van de Vijver et al. (2004) and several Luticola species.

Genus Planothidium Round \& Bukht. (Round \& Bukhtiyarova 1996)

Planothidium wetzelectorianum Kopalová, Zidarova \& Van de Vijver sp. nov. Figs $25-57$

\section{Etymology}

The species is named after our dear friends and colleagues Dr. Carlos Wetzel and Prof. Luc Ector [Luxembourg Institute of Science and Technology (LIST)] in recognition of the long and fruitful collaboration we had (and have) with these two excellent diatom scientists.

\section{Type}

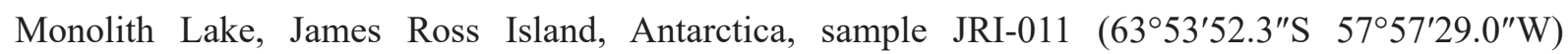
(leg. L. Nedbalová), coll. date: 1 Feb. 2008 (holo-: slide no. BR-4437; iso-: slide PLP-293, University of Antwerp, Belgium).

\section{Description}

\section{Light microscopy (Figs 25-52)}

Frustules in girdle view nearly straight to weakly curved (Fig. 25). Valves linear-elliptical becoming elliptical in smaller specimens. Valve margins convex with broadly rounded, never protracted apices. Neither cavum nor sinus present. Valve dimensions $(\mathrm{n}=25)$ : length $5.5-10.0 \mu \mathrm{m}$, width $2.6-3.2 \mu \mathrm{m}$. Raphe valve (Figs 26-38): axial area very narrow. Central area absent or weakly enlarged due to shortening of two central striae. Raphe straight, difficult to see in LM. Proximal raphe endings indistinct, straight. Distal endings not discernible. Transapical striae weakly radiate throughout the entire valve, clearly broader than the virgae, $14-15$ in $10 \mu \mathrm{m}$. Areolae not discernible. Rapheless valve (Figs 39-52): axial area very narrow, linear. Central area asymmetrically enlarged due to shortening of one central stria, never forming fascia. Striae radiate throughout, more radiate near the apices, as broad as or broader than the virgae, $16-18$ in $10 \mu \mathrm{m}$.

\section{Scanning electron microscopy (Figs 53-57)}

Raphe valve (Figs 53-55): raphe branches almost straight terminating in indistinct straight pores (Fig. 53). Distal fissures absent (Fig. 54). Raphe terminating immediately beyond the last stria (Fig. 54). Striae composed of 3-5 rows of small, rounded areolae (Figs 53, 54). Near the axial area, each stria composed of usually $4-5$ rows of areolae, towards the valve margin only 3 rows of areolae present in the 

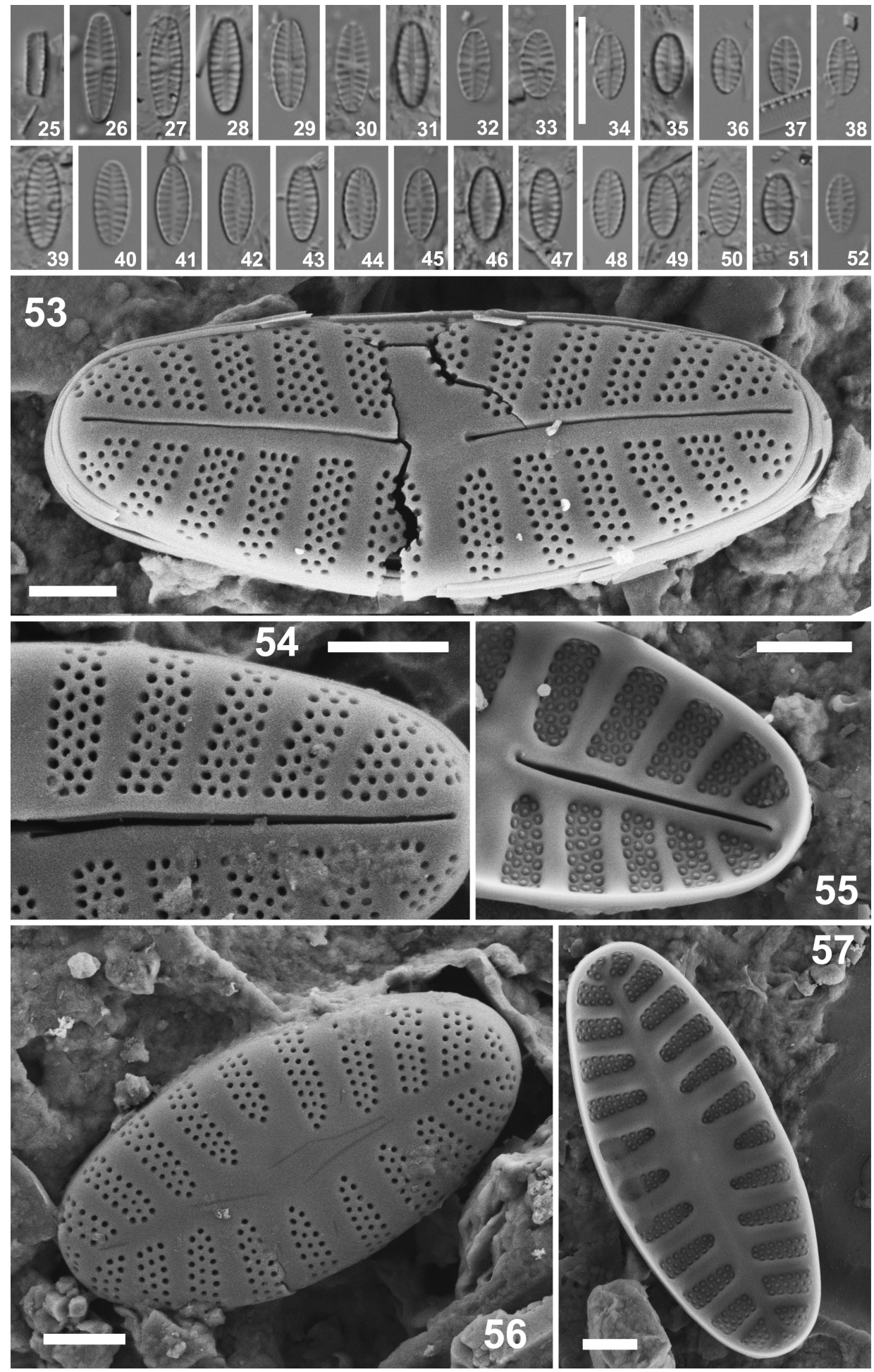

Figs 25-57. Planothidium wetzelectorianum Kopalová, Zidarova \& Van de Vijver sp. nov. Light and scanning electron micrographs of the type population in Monolith Lake (James Ross Island). 25. LM view of a girdle view. 26-38. LM views of raphe valves. 39-52. LM views of rapheless valves. 53. SEM external view of an entire raphe valve. 54. SEM external detail of the areolae. 55. SEM internal view of the raphe and the striae. Note the hymenes on the areolae. 56. SEM external view of an entire rapheless valve. 57. SEM internal view of an entire rapheless valve. Scale bars represent $10 \mu \mathrm{m}$ for Figs 25-52, $1 \mu \mathrm{m}$ for Figs 53-57. 
stria (Fig. 54). Virgae clearly narrower than the striae (Fig. 53). Striae only shortly continuing onto the mantle (Fig. 53). Internally areolae covered by star-shaped hymenes (Fig. 55). Virgae clearly thickened and raised. Proximal raphe endings short, deflected (Fig. 55). Distal endings terminating onto small helictoglossae (Fig. 55). Rapheless valve (Figs 56-57): axial area weakly lanceolate. Striae always composed of 3 rows of small, rounded areolae (Fig. 56). Towards the axial area, striae becoming narrower (Fig. 56). Virgae usually as broad or slightly narrower than the striae (Fig. 56). Asymmetric central area clearly observable. Internally areolae covered by hymenes (Fig. 57). Virgae clearly thickened (Fig. 57).

\section{Ecology and distribution}

Planothidium wetzelectorianum sp. nov. was only found on James Ross Island in the epilithon and epipelon of Monolith Lake on the Ulu Peninsula. This relatively large lake has an almost circumneutral $\mathrm{pH}$ (7.2), a rather lower conductivity value $(120 \mu \mathrm{S} / \mathrm{cm})$ and low nutrient and sulphate values. The samples are dominated by several taxa from the $N$. perminuta complex [N. kleinteichiana Hamsher et al. (Hamsher et al. in press), $N$. velazqueziana Hamsher et al. (Hamsher et al. in press) and $N$. annewillemsiana Hamsher et al. (Hamsher et al. in press)], Humidophila australis (Van de Vijver \& Sabbe) Lowe et al. (Lowe et al. 2014) and Achnanthidium australexiguum Van de Vijver in Taylor et al. (2014).

Genus Psammothidium Bukht. \& Round (Bukhtiyarova \& Round 1996)

Psammothidium confusoneglectum Kopalová, Zidarova \& Van de Vijver sp. nov. Figs 58-85

\section{Etymology}

The specific epithet refers to the possible confusion with Psammothidium confusum (Manguin) Van de Vijver.

\section{Type}

Byers Peninsula, Livingston Island, South Shetland Islands, Antarctica, sample BYM-051 (62 $38^{\prime} 20.1^{\prime \prime} \mathrm{S}$ $61^{\circ} 06^{\prime} 44.2^{\prime \prime}$ W) (leg. B. Van de Vijver), coll. date: 15 Jan. 2009 (holo-: slide no. BR-4438; iso-: slide PLP-294, University of Antwerp, Belgium).

\section{Description}

\section{Light microscopy (Figs 58-82)}

Valves broadly elliptic-lanceolate with clearly convex margins gradually tapering towards the broadly rounded, non-protracted apices. Valve dimensions $(n=30)$ : length $9-12 \mu \mathrm{m}$, width $3.8-4.5 \mu \mathrm{m}$. Raphe valve (Figs 58-70): axial area narrow, linear, not widening towards central area. Central area forming a rectangular to bow-tie-shaped fascia with occasionally one to several shortened striae near the valve margins (Figs 62-64, 68). Raphe straight with almost indistinct, straight proximal endings. Distal fissures not discernible in LM. Transapical striae weakly radiate near the central area, becoming more radiate towards the apices, 30-34 in $10 \mu \mathrm{m}$. Areolae not discernible in LM. Rapheless valve (Figs 71-82): axial area very narrow, linear distinctly widening towards the central area. Central area rounded to apically elliptical, bow-tie shaped widening towards the valve margins, almost forming a fascia. Regularly, shortened striae present near the valve margins. Transapical striae weakly radiate throughout becoming more radiate towards the apices, 33-36 in $10 \mu \mathrm{m}$.

\section{Scanning electron microscopy (Figs 83-85)}

Raphe valve (Fig. 83): striae uniseriate, composed of small, rounded to rectangular areolae, the largest areolae located close to the axial area. Number of areolae per stria diminishing towards the axial area. Near valve margins, last areola transapically elongated, slit-like. A row of slit-like areolae present on the 

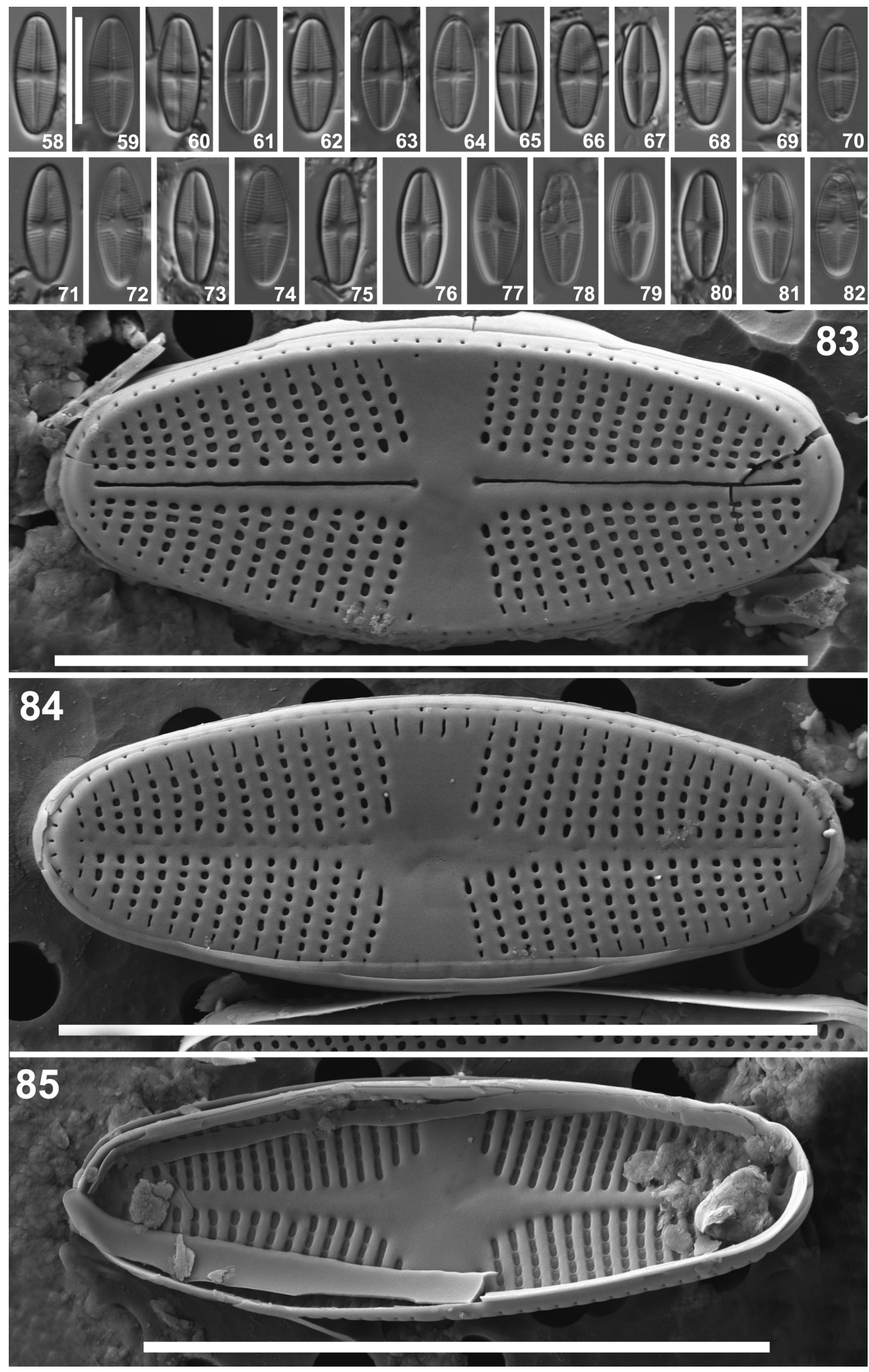

Figs 58-85. Psammothidium confusoneglectum Kopalová, Zidarova \& Van de Vijver sp. nov. Light and scanning electron micrographs of the type population on Byers Peninsula (Livingston Island). 58-70. LM views of raphe valves. 71-82. LM views of rapheless valves. 83. SEM external view of an entire raphe valve. 84. SEM external view of an entire rapheless valve. 85. SEM internal view of an entire rapheless valve. Scale bars represent $10 \mu \mathrm{m}$. 
mantle. Raphe branches almost straight. Proximal raphe endings straight, drop-like expanded (Fig. 83). Distal endings short, weakly drop-like expanded. Rapheless valve (Figs 84-85): central area slightly depressed, forming a weak pseudoraphe (Fig. 84). Striae uniseriate composed of small, rounded to rectangular and transapically elongated areolae (Fig. 84). Slit-like areolae present near the valve margins and onto the mantle (Fig. 84). In the central area, several slit-like areolae visible near the valve margin. Internally areolae transapically elongated, covered by individual perforated hymenes (Fig. 85). Virgae slightly raised. Small silica bars separating the areolae (Fig. 85).

\section{Ecology and distribution}

This new species was up to now only observed on Livingston Island. The largest population was found living in mosses submerged in a large lake showing a circumneutral $\mathrm{pH}(7.3)$ and a low conductivity level $(<100 \mu \mathrm{S} / \mathrm{cm})$. The sample was dominated by several Psammothidium taxa such as $P$. subatomoides (Hust.) Bukht. \& Round (Bukhtiyarova \& Round 1996), P. abundans (Manguin) Bukht. \& Round (Bukhtiyarova \& Round 1996) and P. papilio (D.E.Kellogg, Stuiver, T.B.Kellogg \& Denton) Kopalová \& Van de Vijver in Kopalová et al. (2012).

Psammothidium superpapilio Kopalová, Zidarova \& Van de Vijver sp. nov. Figs 86-109

\section{Etymology}

The specific epithet refers to the similarity with $P$. papilio and the larger valve dimensions.

\section{Type}

Byers Peninsula, Livingston Island, South Shetland Islands, Antarctica, sample BYM-008 (62 $40^{\prime} 11.3^{\prime \prime} \mathrm{S}$ $61^{\circ} 08^{\prime} 45.3^{\prime \prime} \mathrm{W}$ ) (leg. B. Van de Vijver), coll. date: 9 Jan. 2009 (holo-: slide no. BR-4439; iso-: slide PLP-295, University of Antwerp, Belgium).

\section{Description}

\section{Light microscopy (Figs 86-105)}

Valves lanceolate to lanceolate-elliptic with convex to sometimes more straight margins gradually tapering towards the broad cuneately rounded apices. Valve dimensions $(\mathrm{n}=40)$ : length $15-20 \mu \mathrm{m}$, width 4.5-5.5 $\mu \mathrm{m}$. Raphe valve (Figs 96-105): valves clearly convex. Axial area narrow, linear, almost not widening towards the central area. Central area forming a broad rectangular to bow-tieshaped subfascia with several (3-5) shortened striae present near the valve margins. Raphe straight with indistinct, straight proximal endings. Distal fissures not discernible in LM. Transapical striae weakly radiate near the central area, becoming more strongly radiate towards the apices, 28-30 in $10 \mu \mathrm{m}$. Areolae not discernible in LM. Rapheless valve (Figs 86-95): thickened marginal crest clearly visible in LM. Axial area very narrow, linear-lanceolate, clearly widening towards the central area. Pseudoraphe clearly present as a series of irregular depressions in the axial area. Central area rounded to rhombical, bordered by several shortened striae. Fascia never present. Transapical striae weakly radiate throughout becoming more strongly radiate towards the apices, $26-29$ in $10 \mu \mathrm{m}$.

\section{Scanning electron microscopy (Figs 106-109)}

Raphe valve (Figs 106-107): axial area weakly raised and more heavily silicified (Fig. 106). Striae uniseriate, composed of long series of very small, rounded to rectangular areolae (Fig. 106). Number of areolae per striae diminishing towards the axial area (Fig. 106). On the valve face/margin junction, one transapically elongated areola present. Raphe branches almost straight (Fig. 106). Proximal raphe endings straight, simple, never expanded (Fig. 106). Distal endings short, terminating near the last striae at the apices (Fig. 106). Internally, areolae rectangular, covered by perforated hymenes 

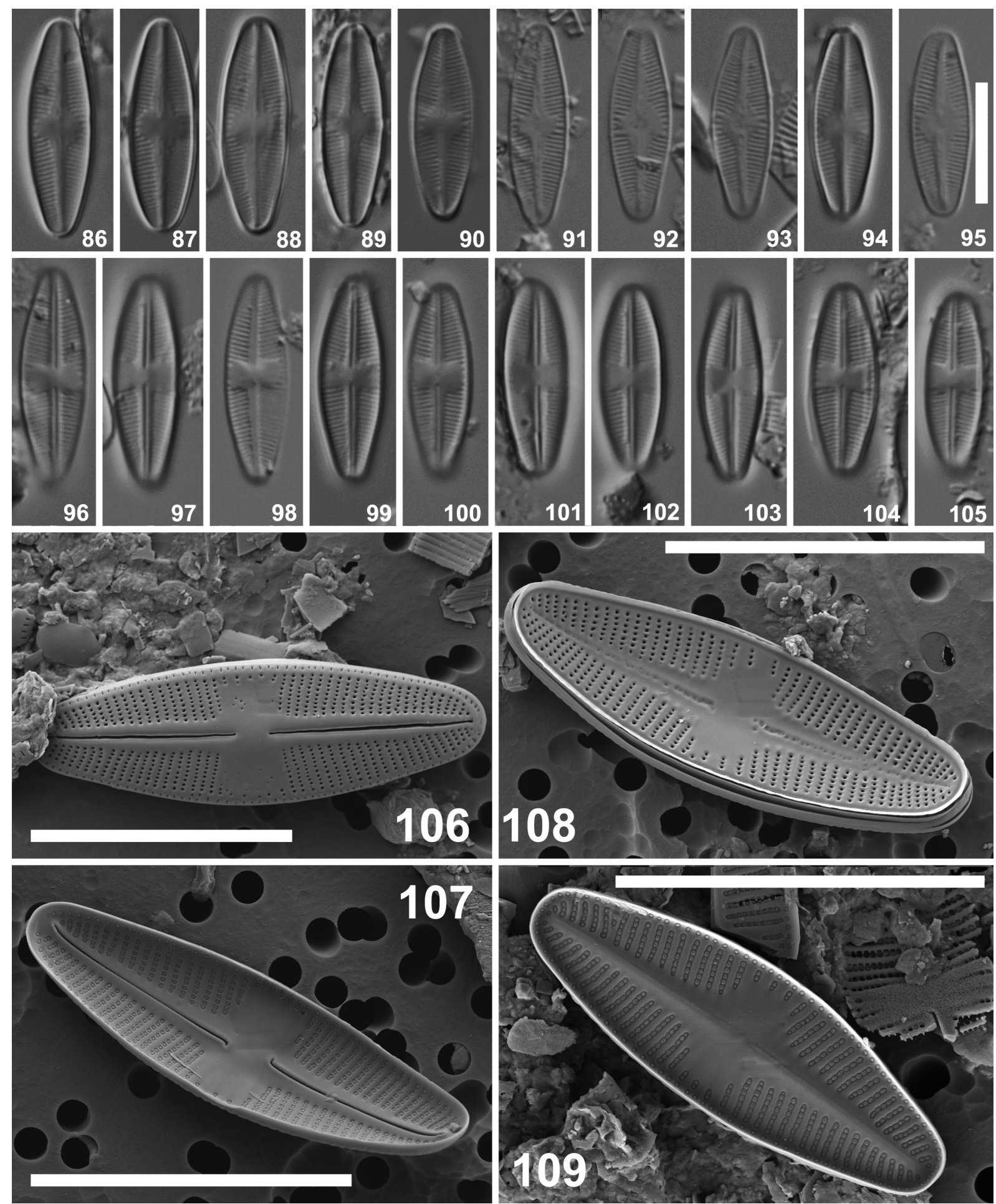

Figs 86-109. Psammothidium superpapilio Kopalová, Zidarova \& Van de Vijver sp. nov. Light and scanning electron micrographs of the type population on Byers Peninsula (Livingston Island). 86-95. LM views of rapheless valves. 96-105. LM views of raphe valves. 106. SEM external view of an entire raphe valve. 107. SEM internal view of an entire raphe valve. 108. SEM external view of an entire rapheless valve. 109. SEM internal view of an entire rapheless valve. Scale bars represent $10 \mu \mathrm{m}$. 
(Fig. 107). Proximal raphe endings bent into opposite directions. Distal endings terminating onto small helictoglossae (Fig. 107). Rapheless valve (Figs 108-109): Valve clearly concave. Thin, raised marginal crest bordering the entire valve. Axial area with irregular depressions, forming a clear pseudoraphe (Fig. 108). Striae uniseriate composed of small, rounded areolae. Internally areolae covered by individual perforated hymenes (Fig. 109). Virgae not raised.

\section{Ecology and distribution}

This new species was up to now only observed with certainty on Livingston Island. The largest population was found living in a terrestrial moss vegetation, at the edge of a shallow lake. The sampling site was clearly influenced by animals with remains of penguins present on the mosses. The sample was dominated by several Psammothidium taxa such as P. germainii (Manguin) Sabbe (Sabbe et al. 2003), P. aretasii (Manguin) Le Cohu (Le Cohu 2005) and P. incognitum (Krasske) Van de Vijver \& Beyens (Van de Vijver et al. 2002).

\section{Discussion}

Although the Antarctic Region is characterized by a large number of Achnanthes, Psammothidium and Planothidium taxa, the new survey nevertheless resulted in the description of four new taxa. When separating these new taxa from all similar taxa known so far worldwide, the entire combination of features of each taxon has been taken into account to justify their status as independent taxa. Valve outline, raphe structure and striation pattern and structure are the main features that are investigated and compared between species.

Recently Tofilovska et al. (2014) revised the type material of $A$. coarctata (Bréb.) Grunow in Cleve \& Grunow (Cleve \& Grunow 1880) and some of its varieties. Based on their and our observations, it is clear that Achnanthes kohleriana sp. nov. belongs to the group of species around A. coarctata: both taxa present a similar position of the rapheless sternum, a comparable orbiculus, a similar raphe structure and similar cribrate areolae. Achnanthes kohleriana sp. nov. can however be easily separated from A. coarctata, often found in aerial habitats in Antarctica (Kopalová et al. 2012), by its valve outline, lacking the prominent constriction in the valve middle, typical for $A$. coarctata, by the marginal ridge which is less developed in A. kohleriana, and the lower stria density (10-11 in A. kohleriana sp. nov., 12-14 in A. coarctata). Achnanthes sinaensis (Hust.) Levkov et al. (Tofilovska et al. 2014) shows a comparable valve outline, although the valve middle is slightly more tumid (Tofilovska et al. 2014) and the apices are weakly protracted and more truncated and less broadly rounded, compared to A. kohleriana sp. nov. The marginal ridge in A. sinaensis is more developed (see for instance Tofilovska et al. 2014, fig. 13c). Moreover, the striae on the mantle in the latter are uniseriate, contrary to A. kohleriana sp. nov. which has biseriate striae on the mantle.

Most other Achnanthes s.s. taxa showing a similar valve outline to A. kohleriana sp. nov., are usually typically marine or brackish taxa such as varieties of A. brevipes C.Agardh (Agardh 1824) or A. parvula Kütz. (Kützing 1844). Achnanthes parvula has smaller valves with a length not exceeding $30 \mu \mathrm{m}$ and coarser areolae (Witkowski et al. 2000). Achnanthes parvula also shows a more laterally located rapheless sternum (McIntire \& Reimer 1974, figs 4a, b), compared to A. kohleriana sp. nov. where the sternum is situated close to the margin. Achnanthes brevipes var. intermedia (Kütz.) P.T.Cleve (Cleve 1895) has a similar valve outline but a slightly coarser striation usually having 3 areolae per stria with much coarser areolae. Additionally, A. brevipes var. intermedia has square-shaped areolae and not rounded as is the case in A. kohleriana sp. nov., Fig. 22 (Toyoda \& Williams 2004). Achnanthes subsessilis Kütz. (Kützing 1833) has a similar valve outline, but narrower valves with a width of around $7 \mu \mathrm{m}$ (Hendey 1951), and not above $9 \mu \mathrm{m}$ as in $A$. kohleriana sp. nov. Internally the central area is clearly panduriform and elevated from the rest of the valve (Blunn \& Evans 1981, fig. 4). Several (poorly known) varieties 
of $A$. subsessilis also show some resemblance. Achnanthes subsessilis var. angusta Cleve \& Möller (Cleve \& Möller 1878) has a very narrow central area (contrary to the relatively broad central area in A. kohleriana sp. nov.). Achnanthes subsessilis var. multiarticulata Kütz. (Kützing 1844), (illustrated by Cox 2006, figs 6, 7 from type slide BM 18469) has a different valve outline with more lanceolate valves with less radiate striae and much smaller central area, as well as a lateral position of the sternum. Moreover, all A. subsessilis varieties are only found in marine conditions whereas $A$. kohleriana sp. nov. is a typical terrestrial taxon. Of the known aerophilic Achnanthes species, a few share similar features to A. kohleriana sp. nov. Achnanthes prominula Levkov \& Tofilovska (Tofilovska et al. 2014), a recently described species from Osogovo, Macedonia, differs in having lanceolate or elliptic-lanceolate valves with narrowly rounded apices (and not linear to linear-elliptic valves with rounded apices), and with slightly coarser striation of 12-13 striae in $10 \mu \mathrm{m}$ with only 5 areolae per stria (Tofilovska et al. 2014), opposite to A. kohleriana sp. nov. where the number of the striae in $10 \mu \mathrm{m}$ does not exceed 12. Several other Achnanthes s.s. taxa are present in the Antarctic Region such as A. muelleri Carlson (Carlson 1913) and A. taylorensis T.B.Kellogg et al. (Kellogg et al. 1980). Although the latter was described from the Antarctic Continent (Kellogg et al. 1980), it was recently observed on James Ross Island in the Maritime Antarctic Region (Kopalová et al. 2012, figs 5C, 5D). Achnanthes taylorensis has smaller valves (length 31-33 $\mu \mathrm{m}$ and width of 8.8-9.3 $\mu \mathrm{m}$ ) with a more lanceolate outline. Achnanthes muelleri, described from South Georgia in (Carlson 1913), has a different valve outline with larger, more rhombiclanceolate valves with clearly convex margins, making confusion with $A$. kohleriana sp. nov. that shows more linear-elliptic valves less likely.

Planothidium wetzelectorianum sp. nov. can be confused with several small-celled Planothidium taxa that all lack the presence of a cavum or a sinus. Several of these species co-occur in the Maritime Antarctic Region. Planothidium renei (Lange-Bert. \& Rol.Schmidt) Van de Vijver in Van de Vijver et al. (2002) has a similar valve outline but differs in having typically only two rows of areolae in both rapheless and raphe valve (Schmidt et al. 1990; Oppenheim 1994). Moreover, P. renei has elongated external distal fissures continuing beyond the last stria whereas $P$. wetzelectorianum sp. nov. has only short distal fissures. The other Antarctic species, P. quadripunctatum (Oppenheim) Sabbe in Sabbe et al. (2003) has typically four rows of small, equally sized areolae per stria separated by very small virgae whereas $P$. wetzelectorianum sp. nov. has 3-4 areolae per stria, separated by rather broad virgae, with the largest areolae in the outer rows and the smaller areolae in the inner rows. Planothidium werumianum Lange-Bert. \& Bąk in Bąk \& Lange-Bertalot (2014) is also quite similar but has a more elliptic valve outline and typically has only 2-3 rows of small rounded areolae, separated by very large virgae, both on the raphid and rapheless valve. The axial area is usually broader (Bąk \& Lange-Bertalot 2014). Finally, Planothidium granum (Hohn \& Hellerman) Lange-Bert. (Lange-Bertalot 1999) has a different valve outline (elliptic-lanceolate with slightly rostrate apices), narrow virgae separating striae with 4 rows of very small areolae on the rapheless valve and strongly hooked external distal fissures.

Psammothidium confusoneglectum sp. nov. belongs to a group of small Psammothidium species that are widespread in the Antarctic Region. Similar species include P. confusum (Krasske) Bukht. \& Round (Bukhtiyarova \& Round 1996), P. stauroneioides (Manguin) Van de Vijver \& Beyens in Van de Vijver et al. (2002), P. papilio and P. abundans. Psammothidium confusum is the most similar based on valve outline but the latter has a very different rapheless valve morphology with striae composed of maximum three transapically elongated, slit-like areolae (the longest ones being near the margin) and the absence of a clear central area whereas $P$. confusoneglectum sp. nov. has a typical fascia bordered by a series of only one areola. The raphe valve in $P$. confusum has a rectangular central area contrary to the wedge-shaped central area in P. confusoneglectum sp. nov. (Van de Vijver et al. 2002, Le Cohu 2005). Psammothidium abundans, present in the same locality as $P$. confusoneglectum sp. nov. has an almost linear valve outline with broadly rounded, slightly protracted apices contrary to the lanceolate valve outline in $P$. confusoneglectum sp. nov. The striae in P. abundans are more or less parallel in both valves whereas 
they are clearly radiate in P. confusoneglectum sp. nov. (Van de Vijver et al. 2008). Psammothidium papilio, widespread in the Maritime Antarctic Region has a more elliptic valve outline with a typical marginal crest on the rapheless valve, which has never been observed in P. confusoneglectum sp. nov. Moreover, $P$. papilio has a larger, more rounded, never wedge-shaped central area on both valves and a much lower stria density (26-28 in $10 \mu \mathrm{m}$ vs 33-36 in $10 \mu \mathrm{m}$ in $P$. confusoneglectum sp. nov.). The last similar species, Psammothidium stauroneioides has a broad lanceolate valve outline, larger valve dimensions (width 4.5-6.5 $\mu \mathrm{m}$ vs 3.8-4.5 $\mu \mathrm{m}$ ) and a large, lanceolate axial area on the rapheless valve.

Finally, Psammothidium superpapilio sp. nov. can be separated from P. papilio in having larger valve length (15-20 $\mu \mathrm{m}$ vs 9-12 in P. papilio) giving the valves a more slender outlook since the valve width in both species is the same. The valves of $P$. superpapilio sp. nov. have a more lanceolate outline with weakly protracted apices whereas in P. papilio valves usually are elliptic even in the longest valves lacking any protracted apices (Schmidt et al. 1990). The raphe valves of $P$. superpapilio sp. nov. have a larger, more rectangular to even wedge-shaped central area, often forming almost a fascia. Psammothidium papilio on the other hand has a raphe valve with a more rounded to rhomboid central area with several shortened striae, always bordering the central area. Although both species co-occur in some samples, a continuum between $P$. papilio and P. superpapilio sp. nov. has never been noticed, justifying the separation of the two species. Other Psammothidium species such as $P$. abundans or $P$. stauroneioides differ sufficiently in valve outline, striation pattern and dimensions to exclude conspecificity.

\section{Conclusions}

The description of these four new monoraphid species once more confirms the unique character of the Maritime Antarctic non-marine diatom flora. The new data improve our knowledge of the biodiversity and biogeography of the Antarctic diatoms.

\section{Acknowledgements}

This study was supported as a long-term research development project RVO no. 67985939. Samples on Byers Peninsula were taken in the framework of the IPY-Limnopolar Project POL2006-06635 (Ministerio de Ciencia y Tecnologia, Spain). Sampling and observations on Deception Island were done within ДМУ 03/63 Project (Science Fund, Bulgaria) and logistically supported by the Bulgarian Antarctic Institute. Dr. Blagoy Uzunov (University of Sofia) and the staff of 'Decepción' Base are thanked for their help during the field workPart of this research was funded within the BELSPO project CCAMBIO. Dr. Alex Ball and the staff of the IAC laboratory at the Natural History Museum are thanked for their help with the scanning electron microscopy. The authors would like to thank the members of expedition to the Czech J.G. Mendel Antarctic Station for field support and assistance.

\section{References}

Agardh C.A. 1824. Systema Algarum. Adumbravit C.A. Agardh. Lundae Literis Berlingianis, Lund. http://dx.doi.org/10.5962/bhl.title.1829

Barber H.G. \& Haworth E.Y. 1981. A guide to the morphology of the diatom frustule, with a key to the British freshwater genera. Freshwater Biological Association Scientific Publication 44: 1-111.

Bąk M. \& Lange-Bertalot H. 2014. Four small-celled Planothidium species from Central Europe proposed as new to science. Oceanological and Hydrobiological Studies 43: 346-359. http://dx.doi. org/10.2478/s13545-014-0152-9

Blunn G.W. \& Evans L.V. 1981. Microscopical observations on Achnanthes subsessilis, with particular reference to stalk formation. Botanica Marina 24: 193-199. 
Bory de Saint Vincent J.B.M. 1822. Dictionnaire classique d'Histoire Naturelle. Tome 1. Rey \& Gravier, Paris.

Bukhtiyarova L. \& Round F.E. 1996. Revision of the genus Achnanthes sensu lato. Psammothidium, a new genus based on A. marginulatum. Diatom Research 11: 1-30. http://dx.doi.org/10.1080/026924 $\underline{\text { 9X.1996.9705361 }}$

Carlson G.W.F. 1913. Süsswasseralgae aus der Antarktis, Südgeorgien und den Falkland Inseln. Wissenschaftliche Ergebnisse der Schwedischen Südpolar-Expedition 1901-1903, unter leitung von dr. Otto Nordenskjøld: 4 (Botanique): 1-94.

Cleve P.T. \& Möller J.D. 1878. Diatoms. Part III, No. 109-168. Esatas Edquists Boktryckeri, Uppsala.

Cleve P.T. \& Grunow A. 1880. Beiträge zur Kenntniss der Arctischen Diatomeen. Kongliga SvenskaVetenskaps Akademiens Handlingar 17: 1-121.

Cleve P.T. 1895. Synopsis of the Naviculoid Diatoms, Part II. Kongliga Svenska-Vetenskaps Akademiens Handlingar 27: 1-219.

Cox E.J. 2006. Achnanthes sensu stricto belongs with genera of the Mastogloiales rather than with other monoraphid diatoms (Bacillariophyta). European Journal of Phycology 41: 67-81. http://dx.doi. org/10.1080/09670260500491543

Hamsher S., Kopalová K., Kociolek J.P., Zidarova R. \& Van de Vijver B. 2016. The genus Nitzschia on the South Shetland Islands and James Ross Island. Fottea 16 (1):79-102. http://dx.doi.org/10.5507/ fot.2015.023

Hendey N.I. 1951. Littoral diatoms of Chichester Harbour with special reference to fouling. Journal of the Royal Microscopical Society 71: 1-86. http://dx.doi.org/10.1111/j.1365-2818.1951.tb01951.x

Hendey N.I. 1964. An introductory account of the smaller algae of British coastal waters. Part V. Bacillariophyceae (Diatoms). Her Majesty's Stationery Office, London.

Kellogg D.E., Stuiver M., Kellogg T.B. \& Denton G.H.D. 1980. Non-marine diatoms from Late Wisconsin perched deltas in Taylor Valley, Antarctica. Palaeogeography, Palaeoclimatology, Palaeoecology 30: 157-189. http://dx.doi.org/10.1016/0031-0182(80)90055-3

Kellogg T.B \& Kellogg D.E. 2002. Non-marine and littoral diatoms from Antarctic and Subantarctic regions. Distribution and updated taxonomy. Diatom Monographs 1, A.R.G. Gantner Verlag KG, Vaduz.

Kohler T.J., Kopalová K., Van de Vijver B. \& Kociolek P.J. 2015. The genus Luticola D.G.Mann (Bacillariophyta) from the McMurdo Sound Region, Antarctica, with the description of four new species. Phytotaxa 208: 103-134. http://dx.doi.org/10.11646/phytotaxa.208.2.1

Kopalová K., Nedbalová L., de Haan M. \& Van de Vijver B. 2011. Description of five new species of the diatom genus Luticola (Bacillariophyta, Diadesmidaceae) found in lakes of James Ross Island (Maritime Antarctic Region). Phytotaxa 27: 44-60. http://dx.doi.org/10.11646/phytotaxa.27.1.5

Kopalová K., Veselá J., Elster J., Nedbalová L., Komárek J. \& Van de Vijver B. 2012. Benthic diatoms (Bacillariophyta) from seepages and streams on James Ross Island (NW Weddell Sea, Antarctica). Plant Ecology and Evolution 145: 190-208. http://dx.doi.org/10.5091/plecevo.2012.639

Kopalová K., Kociolek J.P., Lowe R.L., Zidarova R. \& Van de Vijver B. 2015. Five new species of the genus Humidophila (Bacillariophyta) from the Maritime Antarctic Region. Diatom Research 30: 117-131. http://dx.doi.org/10.1080/0269249X.2014.998714

Kützing F.T. 1833. Synopsis Diatomacearum oder Versuch einer systematischen Zusammenstellung der Diatomeen. Linnaea 8: 529-620. 
Kützing F.T. 1844. Die kieselschaligen. Bacillarien oder Diatomeen. W. Köhne, Nordhausen. http:// dx.doi.org/10.5962/bhl.title.64360

Lange-Bertalot H. 1993. 85 Neue Taxa und über 100 weitere neu definierte Taxa ergänzend zur Süßwasserflora von Mitteleuropa. Bibliotheca Diatomologica 27, J. Cramer, Berlin \& Stuttgart.

Lange-Bertalot H. 1999. Neue Kombinationen von Taxa aus Achnanthes Bory (sensu lato). Iconographia Diatomologica 6: 276-289. Koeltz Scientific Books, Königstein.

Le Cohu R. 2005. Révision des principales espèces dulçaquicoles d'Achnanthales (Bacillariophyta) des îles subantarctiques de Kerguelen. Algological Studies 116: 79-114. http://dx.doi.org/10.1127/1864$\underline{1318 / 2005 / 0116-0079}$

Lowe R.L., Kociolek J.P., Johansen J.R., Van de Vijver B., Lange-Bertalot H. \& Kopalová K. 2014. Humidophila gen. nov., a new genus for a group of diatoms (Bacillariophyta) formerly within the genus Diadesmis: species from Hawai'i, including one new species. Diatom Research 29: 351-360. http:// dx.doi.org/10.1080/0269249X.2014.889039

McIntire C.D. \& Reimer C.W. 1974. Some marine and brackish-water Achnanthes from Yaquina Estuary, Oregon (U.S.A.). Botanica Marina 17: 164-175. http://dx.doi.org/10.1515/botm.1974.17.3.164

Medlin L.K. \& Kaczmarska I. 2004. Evolution of the diatoms: V. Morphological and cytological support for the major clades and a taxonomic revision. Phycologia 43: 245-270. http://dx.doi.org/10.2216/ i0031-8884-43-3-245.1

Ohtsuka T., Kudoh S., Imura S. \& Ohtani S. 2006. Diatoms composing benthic microbial mats in freshwater lakes of Skarvness ice-free area, East-Antarctica. Polar Bioscience 20: 113-131.

Oppenheim D.R. 1994. Taxonomic studies of Achnanthes (Bacillariophyta) in freshwater maritime antarctic lakes. Canadian Journal of Botany 72: 1735-1748. http://dx.doi.org/10.1139/b94-214

Round F.E., Crawford R.M. \& Mann D.G. 1990. The diatoms: biology and morphology of the genera. Cambridge University Press, Cambridge.

Round F.E. \& Bukhtiyarova L. 1996. Four new genera based on Achnanthes (Achnanthidium) together with a re-definition of Achnanthidium. Diatom Research 11:345-361. http://dx.doi.org/10.1080/02692 $\underline{\text { 49X.1996.9705389 }}$

Sabbe K., Verleyen E., Hodgson D.A., Vanhoutte K. \& Vyverman W. 2003. Benthic diatom flora of freshwater and saline lakes in the Larsemann Hills and Rauer Islands, East Antarctica. Antarctic Science 15: 227-248. http://dx.doi.org/10.1017/S095410200300124X

Schmidt R., Mäusbacher R. \& Müller J. 1990. Holocene diatom flora and stratigraphy from sediment cores of two Antarctic lakes (King George Island). Journal of Paleolimnology 3: 55-74. http://dx.doi. org/10.1007/BF00209300

Silva P.C. 1962. Classification of algae. In: Lewin R.A. (ed.) Physiology and biochemistry of algae: 827-837. Academic Press, New York \& London.

Taylor J.C., Cocquyt C., Karthick B. \& Van de Vijver B. 2014. Analysis of the type of Achnanthes exigua Grunow (Bacillariophyta) with the description of a new Antarctic diatom species. Fottea 14: 43-51. http://dx.doi.org/10.5507/fot.2014.003

Tofilovska S., Wetzel C.E., Ector L. \& Levkov Z. 2014. Observation on Achnanthes Bory sensu stricto (Bacillariophyceae) from subaerial habitats in Macedonia and comparison with the type material of A. coarctata (Brébisson ex W. Smith) Grunow, A. coarctata var. sinaensis Hustedt and A. intermedia Kützing. Fottea 14: 15-42. http://dx.doi.org/10.5507/fot.2014.002 
Toyoda K. \& Williams D.M. 2004. Description of Achnanthes Bory (Bacillariophyceae) based on Kützing's type slides and materials I: New morphological information on Achnanthes brevipes var. intermedia (Kütz.) Cleve. Diatom 20: 159-165. http://dx.doi.org/10.11464/diatom1985.20.0_159

Van de Vijver B., Frenot Y. \& Beyens L. 2002. Freshwater diatoms from Ile de la Possession (Crozet archipelago, Subantarctica). Bibliotheca Diatomologica 46, J. Cramer, Berlin \& Stuttgart.

Van de Vijver B., Beyens L. \& Lange-Bertalot H. 2004. The genus Stauroneis in the Arctic and (sub-) Antarctic regions. Bibliotheca Diatomologica 51, J. Cramer, Berlin \& Stuttgart.

Van de Vijver B., Kelly M., Blanco S., Jarlman A. \& Ector L. 2008. The unmasking of a sub-Antarctic endemic: Psammothidium abundans (Manguin) Bukhtiyarova et Round in European rivers. Diatom Research 23: 233-242. http://dx.doi.org/10.1080/0269249X.2008.9705749

Van de Vijver B., Mataloni G., Stanish L. \& Spaulding S.A. 2010. New and interesting species of the genus Muelleria (Bacillariophyta) from the Antarctic region and South Africa. Phycologia 49: 22-41. http://dx.doi.org/10.2216/09-27.1

Van de Vijver B., Zidarova R., Sterken M., Verleyen E., de Haan M., Vyverman W., Hinz F. \& Sabbe K. 2011. Revision of the genus Navicula s.s. (Bacillariophyceae) in inland water of the Sub-Antarctic and Antarctic with the description of five new species. Phycologia 50: 281-297. http://dx.doi. org/10.2216/10-49.1

Van de Vijver B., Wetzel C., Kopalová K., Zidarova R. \& Ector L. 2013. Analysis of the type material of Achnanthidium lanceolatum Brébisson ex Kützing (Bacillariophyta) with the description of two new Planothidium species from the Antarctic Region. Fottea 13: 105-117. http://dx.doi.org/10.5507/ $\underline{\text { fot.2013.010 }}$

Van de Vijver B. \& Kopalová K. 2014. Four Achnanthidium species (Bacillariophyta) formerly identified as Achnanthes minutissima from the Antarctic Region. European Journal of Taxonomy 79: 1-19. http:// dx.doi.org/10.5852/ejt.2014.79

Van de Vijver B., Zidarova R. \& Kopalová K. 2014. New species in the genus Muelleria (Bacillariophyta) from the Maritime Antarctic Region. Fottea 14: 77-90. http://dx.doi.org/10.5507/fot.2014.006

Van der Werff A. 1955. A new method of concentrating and cleaning diatoms and other organisms. Verhandlungen Internationalen Vereinigung für Theoretische und Angewandte Limnologie 2: 276-277.

Witkowski A., Lange-Bertalot H. \& Metzeltin D. 2000. Diatom flora of marine coasts I. Iconographia Diatomologica 7, Koeltz Scientific Books, Königstein.

Zidarova R., Kopalová K. \& Van de Vijver B. 2012. The genus Pinnularia (Bacillariophyta) excluding the section Distantes on Livingston Island (South Shetland Islands) with the description of twelve new taxa. Phytotaxa 44: 11-37. http://dx.doi.org/10.11646/phytotaxa.44.1.2

Zidarova R., Levkov Z. \& Van de Vijver B. 2014. Four new Luticola taxa (Bacillariophyta) from Maritime Antarctica with an emended description of Luticola truncata Kopalová \& Van de Vijver. Phytotaxa 170: 155-168. http://dx.doi.org/10.11646/phytotaxa.170.3.2

Manuscript received: 22 December 2015

Manuscript accepted: 5 March 2016

Published on: 29 July 2016

Topic editor: Koen Martens

Desk editor: Natacha Beau 
KOPALOVÁ K. et al., New monoraphid species from Maritime Antarctica

Printed versions of all papers are also deposited in the libraries of the institutes that are members of the EJT consortium: Muséum national d'Histoire naturelle, Paris, France; Botanic Garden Meise, Belgium; Royal Museum for Central Africa, Tervuren, Belgium; Natural History Museum, London, United Kingdom; Royal Belgian Institute of Natural Sciences, Brussels, Belgium; Natural History Museum of Denmark, Copenhagen, Denmark; Naturalis Biodiversity Center, Leiden, the Netherlands. 